\title{
Cerebrospinal fluid culture and analysis in paediatric patients with shunt infection
}

\author{
Alivia Retra Kusumowardani ${ }^{1}$, *Prastiya Indra Gunawan ${ }^{2}$, Deby Kusumaningrum ${ }^{3}$, Wihasto \\ Suryaningtyas ${ }^{4}$
}

Sri Lanka Journal of Child Health, 2021; 50(3): 436-441

\begin{abstract}
Background: Shunt insertion is an invasive procedure frequently done in patients with excess cerebrospinal fluid (CSF). It comes with the risk of infection which could be ascertained through CSF examination.
\end{abstract}

Objectives: To present the results of CSF culture and analysis in paediatric patients with shunt infection in Dr. Soetomo General Hospital, Surabaya, Indonesia.

Method: A retrospective study was conducted by reviewing medical records of patients with shunt infection aged $0-18$ years old who were treated from January 2016 to December 2019.

Results: Seventeen cases of paediatric shunt infection were identified in this study. Six (35.3\%) patients belonged to the 1-12 month age group. The aetiology of shunt insertion was hydrocephalus in all cases. Seizure was the most common chief complaint $(23.5 \%)$ at presentation. During hospitalisation, recurrent fever was found in 7 $(41.5 \%)$ cases. CSF analysis showed increased white blood cells in $12(70.6 \%)$ cases, decreased glucose level in $11(64.7 \%)$ cases and elevated protein level $>100 \mathrm{mg} / \mathrm{dl}$ in $12(70.6 \%)$ cases. The most frequently isolated pathogens were Staphylococcus aureus and Staphylococcus epidermidis, each appearing in $4(23.5 \%)$ cases, followed by Escherichia coli in 3 (17.7\%) cases.

Conclusions: In this study paediatric patients with shunt infection showed raised white blood cells, decreased glucose and increased protein level on CSF examination. The most common pathogens

${ }^{1}$ Faculty of Medicine, ${ }^{2}$ Department of Paediatrics, ${ }^{3}$ Department of Microbiology, ${ }^{4}$ Department of Neurosurgery, Universitas Airlangga, Indonesia

*Correspondence: prastiya_ig@yahoo.co.id

https://orcid.org/0000-0003-3199-2826

(Received on 28 July 2020: Accepted after revision on 18 September 2020)

The authors declare that there are no conflicts of interest

Personal funding was used for the project.

Open Access Article published under the Creative

Commons Attribution CC-BY (c) (†) License were Staphylococcus aureus, Staphylococcus epidermidis, and Escherichia coli. Significant resistance to ampicillin was present.

DOI: http://doi.org/10.4038/sljch.v50i3.9692

(Key words: Shunt infection, ventriculo-peritoneal shunt, infection, cerebrospinal fluid, paediatrics).

\section{Introduction}

Shunt insertion is one of the therapeutic measures to divert excess cerebrospinal fluid (CSF). It is an invasive procedure that comes with the risks of infection. One of the risk factors that have been tied to infection is host susceptibility. This predisposition could be found in younger age patients with immature immune systems, causing a great number of infections by commensal or low virulence bacteria. However, results vary between researches, and there has been no previous study to identify bacterial pathogens causing shunt infection in the present facility.

\section{Objectives}

To present the causative bacteria of shunt infection, their drug susceptibility pattern and CSF analysis in Dr. Soetomo General Hospital, Surabaya, Indonesia.

\section{Method}

A retrospective study was conducted in Dr. Soetomo General Hospital, Surabaya, Indonesia. The hospital is a tertiary health facility in East Java and serves as the referral centre for all eastern parts of Indonesia. Data were sourced through patients' medical records. Cases with shunt infection occurring in patients aged $0-18$ years from January 2016 to December 2019 were collected. Observed variables included age, gender, aetiology of shunt insertion, chief complaints, clinical features during hospitalisation, the result of CSF analysis, and the result of CSF culture and its susceptibility pattern. Inclusion criteria were cases with an intracranial manifestation of shunt infection and positive CSF culture. Cases without complete information on observed variables were excluded.

Ethical issues: Ethical clearance was obtained from the Health Research Ethics Committee of Dr. Soetomo General Academic Hospital, Surabaya, Indonesia ( No.1431/KEPK/VIII/2019). As it was a 
retrospective study informed consent was not possible. Confidentiality is assured.

\section{Results}

Out of 119 cases with shunt insertion, 27 (22.7\%) developed infection. However, only 17 cases were eligible for this study. The demographic and clinical characteristics of the 17 patients are shown in Table 1.

Table 1

Demographic and clinical characteristics $(n=17)$

\begin{tabular}{|l|c|}
\hline \multicolumn{1}{|c|}{ Variable } & $\mathbf{n}(\mathbf{\%})$ \\
\hline Gender & $09(52.9)$ \\
Female & $08(47.1)$ \\
Male & $0(0)$ \\
\hline Age group & $06(35.3)$ \\
$<1$ month & $05(29.4)$ \\
1 to 12 months & $05(29.4)$ \\
1 to <3 years & $01(05.9)$ \\
3 to <6 years & $0(0)$ \\
6 to <12 years & \\
12 to 18 years & $05(29.4)$ \\
\hline Aetiology of shunt insertion & $04(23.5)$ \\
Hydrocephalus & $03(17.7)$ \\
Communicating hydrocephalus & $03(17.7)$ \\
Non-communicating & $02(11.8)$ \\
hydrocephalus & \\
Multi-lobulated hydrocephalus & \\
Severe hydrocephalus & $02(11.8)$ \\
\hline Chief complaints & $03(17.7)$ \\
Surgical wound & $02(11.8)$ \\
Shunt displacement & $01(05.9)$ \\
Exposed shunt & $01(05.9)$ \\
Fever & $04(23.5)$ \\
Vomiting & $01(05.9)$ \\
Seizure & $01(05.9)$ \\
Loss of consciousness & $01(05.9)$ \\
Increased head circumference & $01(05.9)$ \\
Shunt leakage & $07(41.5)$ \\
Department transfer & $03(17.7)$ \\
\hline Clinical features during & $07(41.5)$ \\
hospitalisation & \\
Fever & \\
Seizure & \\
No symptoms & \\
\hline Prophylactic antibiotics & \\
Ceftriaxone & \\
Cefazolin & \\
No name provided & \\
\hline
\end{tabular}

Nine $(52.9 \%)$ patients were female and $6(35.3 \%)$ patients were 1-12 months of age. The aetiology of shunt insertion was hydrocephalus in all cases. Frequently appearing chief complaints were seizure in $4(23.5 \%)$ cases and shunt displacement in 3 $(17.7 \%)$ cases. During hospitalisation, fever occurred in $7(41.5 \%)$ cases, while an equal amount showed no additional symptoms. Prophylactic antibiotics were used in all cases, the most common being ceftriaxone, used in $9(52.9 \%)$ cases.
CSF analysis is shown in Table 2.

Table 2: Cerebrospinal fluid analysis $(n=17)$

\begin{tabular}{|c|c|}
\hline Parameter & n (\%) \\
\hline Colour & \\
\hline Colourless & $08(47.1)$ \\
\hline Yellow & $08(47.1)$ \\
\hline Red & $01(05.9)$ \\
\hline Clarity & \\
\hline Clear & $14(82.4)$ \\
\hline Turbid & $03(17.7)$ \\
\hline Clots & \\
\hline Negative & $17(100.0)$ \\
\hline Positive & $0(0)$ \\
\hline$p H$ & \\
\hline 8 & $17(100.0)$ \\
\hline$<$ or $>8$ & $0(0)$ \\
\hline White blood cell count & \\
\hline Pleocytosis ${ }^{*}$ & $12(70.6)$ \\
\hline Normal & $05(29.4)$ \\
\hline Mononuclear: Polymorphonuclear & \\
\hline Polymorphonuclear $>$ Mononuclear & $11(67.4)$ \\
\hline Mononuclear $>$ Polymorphonuclear & $06(35.3)$ \\
\hline Nonne & \\
\hline Positive & $12(70.6)$ \\
\hline Negative & $05(29.4)$ \\
\hline Pandy & \\
\hline Positive & $13(76.5)$ \\
\hline Negative & $04(23.5)$ \\
\hline Glucose & \\
\hline Decreased $^{\varpi}$ & $11(67.4)$ \\
\hline Normal & $06(35.3)$ \\
\hline Total protein $^{+}$ & \\
\hline Slight increase & $02(11.8)$ \\
\hline Moderate increase & $01(05.9)$ \\
\hline Great increase & $08(47.1)$ \\
\hline Very great increase & $04(23.5)$ \\
\hline Normal & $02(11.8)$ \\
\hline
\end{tabular}

* Pleocytosis if $\mathrm{WBC}>50 / \mathrm{mm}^{3}$

${ }^{\varpi}$ Decreased if glucose $<40 \mathrm{mg} / \mathrm{dl}$

+ Slight increase 45-75 mg/dl; Moderate increase 75-100mg/dl; Great increase 100-500mg/dl; Very great increase $>500 \mathrm{mg} / \mathrm{dl}$; Normal $45 \mathrm{mg} / \mathrm{dl}$ or less

CSF analysis showed no colour in $8(47.1 \%)$ cases and was clear in $14(82.4 \%)$ cases. White blood cells (WBC) count above 50/cu mm occurred in 12 $(70.6 \%)$ cases, with polymorphonuclear (PMN) cell predominance in $11(67.4 \%)$ cases. Lowered glucose level below $40 \mathrm{mg} / \mathrm{dl}$ was found in 11 $(67.4 \%)$ cases and an increased protein level of more than $100 \mathrm{mg} / \mathrm{dl}$ appeared in $12(70.6 \%)$ cases.

Identified bacteria from CSF cultures are shown in Table 3. 
Table 3

Identified bacteria from CSF cultures $(n=17)$

\begin{tabular}{|l|c|}
\hline \multicolumn{1}{|c|}{ Culture result } & n (\%) \\
\hline Staphylococcus aureus & $04(23.5)$ \\
Staphylococcus epidermidis & $04(23.5)$ \\
Staphylococcus hominis & $01(05.9)$ \\
Escherichia coli & $03(17.7)$ \\
Pseudomonas aeruginosa & $02(11.8)$ \\
Enterobacter cloacae & $01(05.9)$ \\
Enterococcus faecalis & $01(05.9)$ \\
Acinetobacter lwofii & $01(05.9)$ \\
\hline
\end{tabular}

The most frequently appearing pathogens were Staphylococcus aureus and Staphylococcus epidermidis, each in $4(23.5 \%)$ cases. Staphylococcus aureus was found to be more sensitive to gentamycin, oxacillin, co-trimoxazole, and quinupristin-dalfopristin. Staphylococcus epidermidis was found to be more susceptible to chloramphenicol and fosfomycin. Escherichia coli appeared in $3(17.7 \%)$ cases and were found to be more susceptible to amikacin, piperacillintazobactam, chloramphenicol, fosfomycin, imipenem and meropenem.

\section{Discussion}

The prevalence of shunt infection in the present study lies on the higher end of the spectrum. The rate of infection in other studies was estimated at around $1-20 \%{ }^{1-3}$. This study showed that infection occurred mainly in earlier age groups, similar to several other studies ${ }^{4-6}$. Such occurrence had been described due to immature immune systems and inadequate skin barrier ${ }^{3}$. Age-related changes in normal skin flora were also found to be more concentrated in the head than extremities ${ }^{7}$, which may further increase the risk of infection in children undergoing neurosurgery. As stated in previous studies, one of the main aetiologies of shunt infection is congenital hydrocephalus ${ }^{4,6,8}$, which was also seen in this study. However, other types of hydrocephalus were also present that could indicate underlying infection or haemorrhage.

The most common chief complaints were seizure and shunt displacement, while a frequently present clinical symptom during hospitalisation was fever. Fever is said to be one of the most commonly encountered signs of shunt infection ${ }^{3,6}$. In this study, a low number of fever as the main concern was probably caused by parents' underestimation, mistaking it as a usual self-limiting course of disease. Additionally, the hospital in which this study was conducted was a tertiary health facility, increasing the likelihood that such clinical features may have been handled in the lower facilities. While being closely monitored, fever appeared in almost half of the cases. In another study, altered neurologic status as a sign of shunt infection was found in approximately $30-40 \%$ of patients ${ }^{6}$. The presence of this sign could raise the probability of further neurological complications ${ }^{9}$. Cases with displaced shunt mainly migrated to the genitals or anus.

Cephalosporin was used as prophylactic antibiotics in all cases. The use of these antibiotics was suitable with the most commonly isolated pathogen in this study. It covered gram-positive bacteria with extended coverage to gram-negative in the latest generation. However, susceptibility patterns should be observed as continuous use may induce resistance.

The macroscopic result of CSF analysis was mostly within normal limits, while abnormal results indicated a pathologic process. Yellow colour shows the presence of protein $>150 \mathrm{mg} / 100 \mathrm{ml}$, red shows the presence of blood $>1000$ cells $/ \mathrm{cu} \mathrm{mm}$, and turbidity shows the presence of polymorphonuclear $(\mathrm{PMN})$ cells $>300 / \mathrm{cu} \mathrm{mm}^{10}$. For macroscopic abnormalities to occur, the pathologic process should have occurred in a rather significant way. In that sense, an infection should still be suspected in normal analysis, as this study showed positive culture in all cases. Increased $\mathrm{pH}$ was shown to be a suitable environment for bacterial growth ${ }^{11}$, as it presented in all cases in this study.

The dominance of CSF pleocytosis and PMN cells is a clear indicator of central nervous system infection in an active manner. However, one study found that low white blood cell (WBC) count is a predictor for bad prognosis ${ }^{12}$ and two cases in this study fell into the category. This may increase the likelihood of delayed treatment under the assumption of normal values.

Glucose level below $40 \mathrm{mg} / \mathrm{dl}$ most likely indicates a pathologic process ${ }^{10}$. The lowered amount is possibly due to increased metabolic demand of WBC and bacterial pathogens, therefore taking up CSF storage. Cases with normal glucose levels showed lower WBC count, suggesting its association with WBC activity as there is no remarkable storage depletion on account of relatively lower metabolic demand. Even so, the amount of bacterial load should also be considered.

The majority of protein levels exceeded $100 \mathrm{mg} / \mathrm{dl}$. Escalated level of protein was said to be a risk factor for neurological complications ${ }^{9}$. It resulted from the increase of blood-brain barrier permeability due to inflammatory conditions and presence of persistent increase suggesting continuous inflammation ${ }^{6,10}$. Cases with protein $>100 \mathrm{mg} / \mathrm{dl}$ also appeared to have reduced glucose levels and raised WBC count. This finding is common in central nervous system infection. Cases 
with protein less than $100 \mathrm{mg} / \mathrm{dl}$ showed normal glucose level and WBC count. As WBC count shows defence activity against pathogens, its number corresponds to the severity of infection, and consequently its response, one of which is in the form of cell permeability.

In this study, CSF culture was dominated by normal skin flora, which was also present in other studies $^{3,6,13-16}$. The presence of these bacteria suggest that infection started during surgery through inoculation while shunt was being inserted. Infection by these pathogens usually appeared soon after shunt placement ${ }^{16}$. Commensal bacteria gain their ability to become pathogenic depending on host immunity and access to adequate growth ${ }^{17}$. Predisposing factors of Staphylococcus aureus and Staphylococcus epidermidis infection are surgery and newborns ${ }^{15}$. It fits the findings in this study which was dominated with patients in earlier age group whose immunity is yet immature. The number of bacterial density on the skin prior to surgery could also be taken into account, considering lower amount of bacteria was needed to start an infection in the presence of foreign material ${ }^{7}$.

Escherichia coli infection predominance occurred in other studies ${ }^{18,19}$. These bacteria are normally found in the intestines and may induce infection through the distal shunt end. Two out of three cases with Escherichia coli had shunt displacement to the genitals and anus. Other pathogens are commonly associated with nosocomial infection or related to neurosurgical instrumentation ${ }^{20-22}$. Therefore, the duration of hospitalisation and any condition that may prolong the stay should be considered.

A staphylococcal infection could be treated with beta-lactam antibiotics ${ }^{23}$. However, in this study, resistance towards penicillin, namely ampicillin and penicillin $\mathrm{G}$, had appeared. Oxacillin still showed good response, though one case showed resistance, marking the possibility of emerging hospital-acquired methicillin-resistant $S$. aureus. Fosfomycin was said to have adequate coverage for biofilm produced by Staphylococcus aureus and Staphylococcus epidermidis ${ }^{24}$, presenting good sensitivity results. Empirical therapy for Escherichia coli infections includes ampicillin, gentamycin, and cefotaxime. In this study, empirical therapy showed suitability with the result of susceptibility tests. However, it could be suggested to reduce ampicillin use, noting the considerable amount of resistance to it.

A limitation in this study is its full reliance on the completeness of medical records. Several cases had to be eliminated due to lack of information to make a comprehensive analysis.

\section{Conclusions}

Paediatric patients with shunt infection on CSF analysis had raised white blood cells, decreased glucose, and increased protein level. The most common pathogens were Staphylococcus aureus, Staphylococcus epidermidis, and Escherichia coli. Significant resistance to ampicillin was present in this study.

\section{References}

1. Kliegman RM. Nelson Textbook of Pediatrics Twentieth Edition. Elsevier. 2016.

2. Rotim K, Miklic P, Paladino J, Melada A, Marcikic M, Scap M. Reducing the incidence of infection in paediatric cerebrospinal fluid shunt operations. Child's Nervous System 1997; 13(11-12): 584-7.

https://doi.org/10.1007/s003810050144 PMid: 9454973

3. Lee JK, Seok JY, Lee JH, Choi EH, Phi $\mathrm{JH}$, Kim SK, et al. Incidence and risk factors of ventriculo-peritoneal shunt infections in children: A study of 333 consecutive shunts in 6 years. Journal of Korean Medical Science 2012; 27(12): 1563-8.

https://doi.org/10.3346/jkms.2012.27.12.1 563

PMid: 23255859 PMCid: PMC3524439

4. Reddy GK, Bollam P, Caldito G. Ventriculo-peritoneal shunt surgery and the risk of shunt infection in patients with hydrocephalus: Long-term single institution experience. World Neurosurgery 2012; 78(1-2): 155-63. https://doi.org/10.1016/j.wneu.2011.10.03 4

PMid: 22120565

5. Simon TD, Whitlock KB, Riva-Cambrin J, Kestle JRW, Rosenfeld M, Dean JM, et al. Revision surgeries are associated with significant increased risk of subsequent cerebrospinal fluid shunt infection. Pediatric Infectious Disease Journal 2012; 31(6): 551-6. https://doi.org/10.1097/INF.0b013e31824 da5bd

PMid: 22333701 PMCid: PMC3356497

6. Yakut N, Soysal A, Kepenekli Kadayifci E, Dalgic N, Yllmaz Ciftdogan D, Karaaslan A, et al. Ventriculo-peritoneal shunt infections and re-infections in 
children: a multicentre retrospective study. British Journal of Neurosurgery 2018; 32: 196-200.

https://doi.org/10.1080/02688697.2018.14 67373

PMid: 29706112

7. Pople IK, Bayston R, Hayward RD. Infection of cerebrospinal fluid shunts in infants: A study of aetiological factors. Journal of Neurosurgery 1992; 77(1): 2936.

https://doi.org/10.3171/jns.1992.77.1.0029 PMid: 1607969

8. George R, Leibrock L, Epstein M. Longterm analysis of cerebrospinal fluid shunt infections. A 25-year experience. Journal of Neurosurgery 1979; 51(6): 804-11. https://doi.org/10.3171/jns.1979.51.6.0804 PMid: 501424

9. Namani S, Milenković Z, Koci B. A prospective study of risk factors for neurological complications in childhood bacterial meningitis. Journal of Pediatrics (Rio J) 2013; 89(3): 256-62.

https://doi.org/10.1016/j.jped.2012.10.001 PMid: 23664199

10. Gomez-Beldarrain M, García-Moncó JC. Lumbar puncture and CSF analysis and interpretation. CNS Infection A Clinical Approach Second Ed. 2018; 1-17. https://doi.org/10.1007/978-3-319-702964_1

11. Cunniffe JG, Whitby-Strevens S, Wilcox MH. Effect of $\mathrm{pH}$ changes in cerebrospinal fluid specimens on bacterial survival and antigen test results. Journal of Clinical Pathology 1996; 49(3): 24953.

https://doi.org/10.1136/jcp.49.3.249

PMid: 8675739 PMCid: PMC500408

12. Lin WL, Chi H, Huang FY, Huang DTN, Chiu NC. Analysis of clinical outcomes in paediatric bacterial meningitis focusing on patients without cerebrospinal fluid pleocytosis. Journal of Microbiology, Immunology and Infection 2016; 49(5): 723-8.

https://doi.org/10.1016/j.jmii.2014.08.013 PMid: 25442861

13. Turgut M, Alabaz D, Erbey F, Kocabas E, Erman $\mathrm{T}$, Alhan E, et al. Cerebrospinal fluid shunt infections in children.
Pediatric Neurosurgery 2005; 41(3): 1316.

https://doi.org/10.1159/000085869

PMid: 15995329

14. Farzana K, Noreen S, Nasir B, Azhar S, Mumtaz A, Sethi A, et al. Comparative analysis of minimum inhibitory concentration of various brands of cephalosporin against clinical isolates of staphylococcus aureus. Scientific Research and Essays 2011; 6(31): 6428-34.

https://doi.org/10.5897/SRE11.008

15. Adams DJ, Rajnik M. Microbiology and treatment of cerebrospinal fluid shunt infections in children. Current Infectious Disease Reports 2014; 16(10): 427. https://doi.org/10.1007/s11908-014-04278

PMid: 25129115

16. Paff M, Alexandru-Abrams D, Muhonen M, Loudon W. Ventriculo-peritoneal shunt complications: A review. Interdisciplinary Neurosurgery: Advanced Techniques and Case Management 2018; 13: 66-70.

https://doi.org/10.1016/j.inat.2018.04.004

17. Bernard K. The genus Corynebacterium and other medically relevant coryneformlike bacteria. Journal of Clinical Microbiology 2012; 50(10): 3152-8. https://doi.org/10.1128/JCM.00796-12 PMid: 22837327 PMCid: PMC3457441

18. Lin MC, Chi H, Chiu NC, Huang FY, Ho CS. Factors for poor prognosis of neonatal bacterial meningitis in a medical centre in Northern Taiwan. Journal of Microbiology, Immunology and Infection 2012; 45(6): 442-7.

https://doi.org/10.1016/j.jmii.2011.12.034 PMid: 22571998

19. de Blauw D, Bruning A, Vijn LJ, Wildenbeest JG, Wolthers KC, Biezeveld $\mathrm{MH}$, et al. Blood and cerebrospinal fluid characteristics in neonates with a suspected central nervous system infection. Medicine (Baltimore) 2019; 98(25): e16079. https://doi.org/10.1097/MD.00000000000 16079

PMid: 31232949 PMCid: PMC6636939

20. Agarwal N, Shukla R, Agarwal D, Gupta K, Luthra R, Gupta J, et al. Pediatric ventriculo-peritoneal shunts and their 
complications: An analysis. Journal of Indian Association of Pediatric Surgeons 2017; 22(3): 155-7.

https://doi.org/10.4103/0971-9261.207624

PMid: 28694572 PMCid: PMC5473301

21. Davin-Regli A, Pagès JM. Enterobacter aerogenes and Enterobacter cloacae; Versatile bacterial pathogens confronting antibiotic treatment. Frontiers in Microbiology 2015; 6: 392.

https://doi.org/10.3389/fmicb.2015.00392 PMid: 26042091 PMCid: PMC4435039

22. Tuon FF, Penteado-Filho SR, Amarante D, Andrade MA, Borba LA. Mortality rate in patients with nosocomial Acinetobacter meningitis from a Brazilian hospital. Brazilian Journal of Infectious Diseases 2010; 14(5): 437-40.

https://doi.org/10.1016/S14138670(10)700 90-8
23. Gold HS, Pillai SK. Anti-staphylococcal agents. Infectious Disease Clinics of North America 2009; 23(1): 99-131.

https://doi.org/10.1016/j.idc.2008.10.008 PMid: 19135918

24. Falagas ME, Vouloumanou EK, Samonis G, Vardakasa KZ. Fosfomycin. Clinical Microbiology Reviews 2016; 29(2): 32147.

https://doi.org/10.1128/CMR.00068-15 PMid: 26960938 PMCid: PMC4786888 